primary education. For the second selection we need tests to measure general mental energy in conjunction with verbal ability or with technical ability. Lastly, in the absence of reliable tests for character qualities, the considered opinions of the school staff could be utilized. Not only would this method be simpler than the one now in operation, but it would also free the primary schools from the examination fetish. Having ascertained how many pupils there are who have the capacity to profit by the grammar school or advanced technical instruction, the necessary facilities must be provided. For the others, senior modern schools with sufficient variation to allow for the varying degrees and types of capacities among the pupils are needed.

\section{Research of the Royal College of Surgeons}

THE scientific report of the Royal College of Surgeons of England for the past year reveals the extraordinary diversity of work which is being carried out in the Museum, Research Laboratories and the Buckston Browne Surgical Research Farm, in spite of the fact that work has been severely handicapped by a rebuilding programme which will give the College of Surgeons a unique research unit. There has been great activity in almost every field. In the Museum, the Pathological Curator reports consider. able progress in the renewing of the pathological series, and in the fields of physical anthropology there have been large accessions of human material from archæological excavations in Great Britain and abroad. As for the purely research activities of the College, these have been carried on, although under difficult conditions, in temporary laboratories at St. Bartholomew's Medical School and at the Buckston Browne Research Farm. To mention only a few of the outstanding investigations which have been pursued in the course of the year, great progress has been made in the development of operative technique for the treatment of certain forms of heart disease, technique which has been most successful in its clinical applications. Work on the physiology of the urinary system has done much to solve the problem of the nervous control of the pelvis and ureter. Experimental research on nerve grafting, begun the previous year, has been continued, and is producing results which are of the greatest interest. Of particular importance from a practical point of view is the work on high blood pressure, which disease has been reproduced in the experimental animal, and has been found to resemble closely in its clinical features and histology arterial hypertension in the human. A fundamental problem which has been tackled is that of the relation of the central nervous system to carbohydrate metabolism and heat regulation, and we look forward with considerable interest to the further fruits of these investigations.

\section{Publications of the Linnean Society}

THE first part of the Proceedings of the Linnean Society for the 150th session (1937-38) has appeared. It contains the acta of the Society at meetings from that of October 28 to that of December 9 ; it em- bodies in full three of the papers read at the meetings, and abstracts of the others, whether reserved for printing in the Journal of the Society or not. It is exactly a hundred years since the Society began to print the Proceedings. At first they appeared two to five times during a session, in sheets of eight or sixteen pages, by which method during the ten years 1838-1848 the average interval between the making of a communication to the Society and its record in print was six months; and during the seven years 1848-1855 it was seven months. In 1856 the Society began to issue its Proceedings of an entire year after the end of the session and continued to do so for seventy-four years, except that between 1860 and 1872 they appeared each year in two, three or four parts as ready.

In 1930 , the Society reverted to publication by sheets, issuing sixteen pages together or multiples of sixteen. There were nine parts containing the acta of the session 1930-31; but, as this entailed excessive charges for postage, the parts were enlarged in order to reduce their number so that they were in the successive years six, five, four and five. In 1935 it was determined that four should be the number of parts in each year ; and so it remains. The part. just issued is the first part for the session 1937-38. The interval between the reading of the first paper recorded in it and its appearance from the press has been only two months. Slight changes have been made in the format by the use of bold type and spacing so as to make the record fall conveniently into chapters, and to lead the reader quickly to what he wishes to find. The Society is to continue its endeavour to obtain an attractive, as well as a prompt, publication.

\section{Safeguards Against Interruptions of the Electric Supply}

THE public and industry now use electricity so largely that any interruption in the continuity of the supply is a serious matter which needs careful consideration. Two factors that accentuate this need are first the increasing growth and interconnexion of generating plant, leading to increased risk of serious damage on the occurrence of a fault, and secondly the increasing tendency to faults occasioned. by the extended use of overhead lines for long. distance interconnexion and for supplying rural areas. In a paper on this subject read to the Institution of Electrical Engineers on January 6 by H. W. Clothier, B. H. Leeson and H. Leybourn, a full statement of the problem is given, and the best way of countering the risks run are considered for the various methods of supply. Particulars are given of high-speed smalloil-volume switches capable of breaking the circuit by utilizing in improved ways well-tried principles, and of an automatic reclosing 132 kilovolt oil circuitbreaker with an are-duration of only one cycle of the current at full rating. It is claimed that when a fault has developed in a component of a supply system provided with protective safeguards of the automatic instantaneous protection type and fastacting circuit-breakers, very little damage if any is done to the faulty component and there is practically 
no interruption to the supply. If a fault were to system, the sustained feeding of power into it would probably lead to a serious breakdown and fire, with the risk of a long-maintained interruption of the supply. Occurrences of this nature have taken place during the last few years due, for example, to leakages from transient faults on overhead lines and leakages due to fires resulting from sustained arcing on unprotected apparatus. These risks are uneconomic and should be guarded against by safeguards of the type described in this paper, adequate to protect the network from damage.

\section{New Museum of the University of Colorado}

Prof. T. D. A. Cockerell writes : "When I came to the University of Colorado in 1904, there was no museum. Judge Junius Henderson, a lawyer, but also a very keen amateur naturalist, became honorary develop in an unprotected component of a supply

\section{Archæological Discovery at Sakkara, Egypt}

THE discovery at North Sakkara, forty miles south of Cairo, of a tomb which it is thought may prove to be that of Menes, the first king of the First Dynasty of Egypt (c. 3300 B.c.), is of exceptional interest, both on account of its historical associations, and also in view of the fact that the tomb of this monarch had been thought to have been discovered many years ago by Sir Flinders Petrie at Abydos. The grounds for this tentative attribution of the tomb now found are the hundred or more clay sealings bearing the name 'Aha', generally identified as that of King Menes, and the fact that no other name appears. The discovery was made by Mr. Walter Emery, who has been engaged in excavation on the site for the past three years. Of all the tombs brought to light here up to the present, this is the largest. It contains five chambers. Its roof had fallen in and it had been plundered; but according to the reports in The Times of January 7-8, associated with the skeletal remains of two aged individuals was a large number of antiquities, of which the most important are quantities of stone and alabaster jars, many inscribed with the name of the king. The pottery includes shapes not hitherto recorded in Egypt. In addition to slate palettes there are fragments of funerary furniture, among which are the traditional ivory bull's legs of chairs and parts of a wooden bed similar in design to that already known as belonging to Queen Hetepheres of the Fourth Dynasty. A novel feature of the tomb is the coloured reed matting, which was affixed to the clay walls while they were still wet, forming, it is pointed out, a primitive kind of wall-paper. Many

MUSEUM OF UnIVERSITY OF Colorado

curator of the then insignificant collections. Owing to his energy and enthusiasm, the collections grew, and in course of time Henderson was made professor, and giving up his law, devoted his whole time to the Museum. Until recently, the collections were housed in one wing of a building devoted to instruction, and having become very extensive, were crowded so that it was difficult to find room for anything more. The collection of molluses, in particular, is one of the best in America, and the many fossils include the types of numerous species of insects, shells and plants. The Museum has now moved into a new building, shown herewith. There are fine exhibition galleries for the zoological specimens, for the fossils and minerals, and for the important collections gathered by Earl Morris, representing the work of the ancient inhabitants of south-western North America. It is greatly regretted that Junius Henderson died on November 4, after a very long illness, and was not able to see the fruition of his years of labour in the new building. He has been succeeded by Prof. Hugo Rodeck." of the sealings bear inscriptions in black ink. Mr. Emery proposes to excavate below the adjoining Third Dynasty tombs in the hope that the discovery of the burial places of the king's servants will confirm the tentative attribution of the tomb to Menes.

\section{Recent Acquisitions by the British Museum}

IN the announcement of the additions to the archæological and ethnographical collections of the British Museum (Bloomsbury) during the past month it is stated that the antiquities from Skara Brae, Orkney, which were deposited in the collections on loan in 1933 have now been given to the Museum by the owner, Mr. Walter G. Grant. It will be remembered that this site was excavated by Prof. Gordon Childe, whose careful investigation of this remarkable prehistoric town, or village, revealed a picture of early culture so complete as to constitute on its primitive scale something in the nature of a 'Knossos' of the north. Among other antiquities accruing to the Museum are the remarkable and important collections 